\title{
An Analytical Literature Review of State of Art Works on Online Social Media Platforms
}

\author{
Namrata P. Bhatt \\ Lecturer (Adhoc), \\ Narmada College of Science and Commerce \\ Bharuch, Gujarat, India - 392011
}

\author{
Jatinderkumar R. Saini, Ph.D \\ Director I/C \& Associate Professor, \\ Narmada College of Computer Application \\ Bharuch, Gujarat, India - 392011
}

\begin{abstract}
There are various online media platforms available today and include Facebook, LinkedIn, YouTube, StumbleUpon, Digg, Reddit, Del.icio.us, Pinterest, Tumbler and Google+, to name a few. Such platforms are exploited by individuals as well as masses for different purposes ranging from communicating with relatives and friends to using them for online marketing. With the proliferation of such online media platforms, the world has converged and the effect of the virality of such platforms on general society is tremendous. The current paper presents an analytical review of related literature and on the sidelines also aims at identifying the parameters responsible for influencing the usage and popularity of such platforms. The factors responsible for the selection of a specific platform as well as the stages, effects and growth of news-items leading them to become viral have also been studied.
\end{abstract}

\section{Keywords}

Buzz marketing, Online Social Media, Social Analysis, Viral Video, word-of-mouth (WOM).

\section{INTRODUCTION}

According to Wikipedia [21], Social media are a platform where a number of people can interact with each other over networks and thereby share information of interest. Stelzner [14] concludes that $86 \%$ of marketers use social media for their business. Further, he concluded that Facebook and LinkedIn today are most important social media and when forced to select only one, $49 \%$ of marketers selected Facebook while $16 \%$ selected LinkedIn. For the remaining 35\% share, the other marketing strategies were used. As per Wikipedia [21], Interactions done by the users of social media, including Facebook and LinkedIn causes social media contents to be generated.

Facebook was founded on February 4, 2004, by Mark Zuckerberg with his college roommates and fellow Harvard University students Eduardo Saverin, Andrew McCollum, Dustin Moskovitz and Chris Hughes. According to Wikipedia [22], Initially Facebook's membership was available only for Harvard students, but later expanded it to colleges in the Boston area, the Ivy League, and Stanford University. Gradually, support for students of other universities and high school were included. Today, anyone who claims to be at least 13 years old worldwide can register, although no proof is needed. On the other hand, LinkedIn was founded on December 2002 and was launched on $5^{\text {th }}$ May 2003. Wikipedia [23] concluded that LinkedIn is considered to be a business-oriented social networking service used mainly for professional networking. In 2006, LinkedIn increased to 20 million viewers. Hempel and Hilderbrand [6, 7] argued that as of June 2013, LinkedIn acquires more than 259 million users from more than 200 countries and territories.

Steven [24] concludes that after Facebook, second-largest social networking website is Google+. According to
Marketing land [10], there are approximately 540 monthly active users. According to Wikipedia [25], Tumbler is another social networking website and micro blogging platform that allows users to post multimedia contents. According to Tumbler [16], Tumbler records the hosting of over 201.3 blogs as of September 1, 2014.There are many more social networking sites available nowadays. Most important of all is how contents uploaded are getting viral. Jess [26] argued that Spike and Growth are two patterns of the contents getting viral. Further, he concluded that Spike patterns imply that content suddenly gets popular and gets viral on social media within less time but gets down soon while Growth patterns imply that content slowly grows over time and stays viral for long periods, implying a slow and steady growth.

Talking about twitter, according to The Big Wiki [27], it is an online social networking service that was created in March 2006 by Jack Dorsey, Evan Williams, Biz Stone and Noah Glass and by July 2006 site was launched. According to Twitter [17], like Facebook and other popular social networking sites, Twitter was also warmly welcomed by more than 100 million users who in 2012 posted 340 million tweets per day. Another site that allows people to share videos is YouTube. According to Wikipedia [28], the service was created by three former PayPal employees in February 2005 and has been owned by Google since late 2006 while Wikipedia [29] concludes that StumbleUpon allows users to rate photos, videos, web pages according to their interest, but it is a discovery engine and do not fit our topic. Another one is Digg which is according to Wikipedia [30] a popular social news website that allows users to vote web contents up or down, called digging and burying, respectively. Further, they concluded that Digg's popularity encouraged the creation of similar social networking sites with story submission and voting systems such as Reddit.

\section{LITERATURE REVIEW}

Saini and Desai $[32,34]$ have provided the structural and textual analysis respectively for username segment of email identifiers and digits used for group address identifiers of Yahoo. Saini [31] has provided an in-depth categorization of online mail spam while in another work [33], he has presented the psychology based analysis of cyber conduct of chatters. According to University of California, Yale [19], moods can get spread virally over social media like Facebook. According to them, what people feel and say in one place may spread to many parts of the globe on the very same day. The researchers (some of whom were Facebook employees) analyzed the emotional content of billions of updates posted to Facebook between January 2009 and March 2012.They found that negative Facebook posts increased by $1.16 \%$ and positive posts decreased by $1.19 \%$ in response to the gloomy weather. On the other hand, Fisher [3] concluded that, of the 70 percent of consumers who had visited a social media site to get information, 49 percent of these customers made a purchase decision with this information they found while 
others they are likely to pass on information they find online. Subramani and Rajagopalan [15] found that viral marketing, also known as word-of-mouth (WOM) or 'buzz marketing' is the tactic of creating a process where interested people can market to each other.

Pharmaceutical manufacturer Johnson \& Johnson released an online marketing campaign via an online video about pain relief for women who carry their babies in a sling. Baker [1] found that within hours, Twitter exploded with negative commentary about the video's perceived denigration (criticize unfairly) of motherhood. Heath [5] concluded that people prefer passing on bad news, while Nisbett and Wilson [11] found that people prefer passing on good news because recipients of this good news will then associate the positive mood with the messenger. According to Francesco and Jess [4], different types of videos spread in different ways according to the content appeal to different audiences. Some audiences spread things which they like the most, to show their choices, with positive comments on it, while others spread it, including negative comments to show dislike of a particular thing. For example, the videos related to the Universe and Space become viral as soon as they are uploaded by the respective agencies. A good instance of this is the video of India's recent venture into the Universe through the 'Mangal-Yaan', whose videos became viral as soon as they were uploaded by some users. Another similar example is the advertisement of cosmetic products. A good instance of this is the advertisement of Dove brand, which became viral on a large scale by female users.

According to the research done by Tyler [18], there is a deep connection between elements of videos and videos getting viral. Uniqueness, attractiveness, creativity, presentation, new information, etc. can be considered as elements of viral video. Burgess [2] concludes that 'oddness' and 'amateurism' lead to virality. Hildebrand [7] argues that quick viewing mechanism of YouTube makes skimming videos easy. Users on YouTube can quickly move from video to video to find popular content. Southgate, Westoby and Graham [13] conclude that the presentation of videos is directly related to their popularity. Sagan, Paul and Tom [12] suggest that newsworthiness is a factor in determining a video's viral capability. However, newsworthiness does not act alone in determining the popularity of a video. They further advocate that a news video must also appeal to viewers in the 18-25 age groups to become widely popular. We believe that the LokSabha elections of 2014 of India are an example of this. Another researcher who has written about the newsworthiness of viral videos is Wallsten [20]. He suggests that the blogosphere has attributed to the rise of many viral YouTube videos.

September 2014's unfortunate incident of a zoo in New Delhi, where a boy was killed by a Tiger was captured by some of the visitors and was uploaded to social networking sites. The time within which images and videos of the same got viral was noticeable. The incident was known to each and every part of India within a very-very short period of time. It doesn't mean that in the past this kind of incidents was not taking place but due to less use and awareness of social media sites, news was not getting that much viral. Reason behind these contents getting so viral was that people like to see something unusual and like to judge the situation. Large numbers of comments were given by people based on their thinking and judgment of that situation. Many actors/actresses, politicians, business-icons and other personalities prefer Twitter to keep in touch with their fans and also increase their fans following.
Jason [8] concludes that Facebook is still dominant, but other networks are rising. According to him, Facebook remains number one social networking site, with $83 \%$ of the account. Further, he concluded that some of the other major players recorded small to modest increases between 2012 - 2014 including Google $+(+6 \%)$, LinkedIn $(+9 \%)$ and Twitter $(+2 \%)$ - but the biggest rises in active user numbers were on newer or less-established networks. This trend was led by Instagram $(+23 \%)$ and Reddit $(+13 \%)$. Looking towards an age factor, age group between 25 to 34 is highest social networking sites user. Lupton [9] carried out survey by asking two questions: 1) what social media do you currently use as a part of your academic work? And 2) which of these social media do you find most useful? According to the survey results, from a total of 711 academics, two-thirds $(67 \%)$ of whom were females. Regionally, highest response was from UK (37\%), followed by Australia/New Zealand (25\%), the US (20\%), continental Europe (10\%) and Canada (6\%). The remaining respondents were from Ireland, the Caribbean and countries in Africa, Asia and South America. In terms of career, Most of the respondents were relatively junior: $34 \%$ were early career academics and $26 \%$ were postgraduate students. Mid-career academics comprised $24 \%$ of the respondents, while only $15 \%$ described themselves as senior academics and $1 \%$ as retired academics.

Further, Lupton [9] concluded that $49 \%$ of respondent were from social science, while $18 \%$ were in medicine, $18 \%$ in the humanities and $13 \%$ in science, technology and engineering. Remaining $2 \%$ were of commerce, art, law, library science and so on. In terms of use, Lupton [9] advocates that $90 \%$ of respondent use Twitter as part of their academic work, $60 \%$ uses LinkedIn, 42\% Facebook, 25\% YouTube, 21\% Google+. Other social media tools such as multi-authored blogs (16\%), Pinterest (9\%), SlideShare (13\%), Instagram (3\%), Tumbler $(5 \%)$ attracted few respondents.

\section{FINDINGS AND ANALYSIS}

On the basis of study, it is found that there were many researchers who worked on various social networking sites like Facebook, LinkedIn, etc. The Table 1 highlights the topic of research findings of the particular work reviewed during literature survey. For instance, the first record of Table 1 indicates that Stelzner [14] has elaborated on mainly two issues viz. 'Facebook', and 'LinkedIn', in his paper. Further, record no. 9 in Table 1, is similarly an indication that Subramani and Rajagopalan [15] have provided an at length discussion on topics, namely 'Viral Marketing', 'WOM' and 'Buzz Marketing'.

Based on Table 1, Analysis of research works surveyed is presented in this paper. In order to get the frequency of the specific paper highlight, Table 1 presented such highlights paper-wise.

Table 1. Summary of Literature Review on Social Media Analysis

\begin{tabular}{|c|l|l|}
\hline $\begin{array}{c}\text { Sr. } \\
\text { No. }\end{array}$ & $\begin{array}{c}\text { Research Work } \\
\text { in Literature }\end{array}$ & \multicolumn{1}{|c|}{ Paper Highlight } \\
\hline $\mathbf{1}$ & Stelzner [14] & Facebook, LinkedIn \\
\hline $\mathbf{2}$ & Hempel [6] & LinkedIn \\
\hline $\mathbf{3}$ & Twitter [17] & Twitter \\
\hline
\end{tabular}




\begin{tabular}{|c|c|c|}
\hline 4 & $\begin{array}{l}\text { Marketing Land } \\
{[10]}\end{array}$ & Facebook, Google+ \\
\hline 5 & Tumbler [16] & Tumbler \\
\hline 6 & $\begin{array}{l}\text { University of } \\
\text { California, Yale } \\
\text { [19] }\end{array}$ & Facebook \\
\hline 7 & Fisher [3] & social media \\
\hline 8 & $\begin{array}{l}\text { Subramani and } \\
\text { Rajagopalan [15] }\end{array}$ & $\begin{array}{l}\text { Viral marketing, WOM, Buzz } \\
\text { marketing }\end{array}$ \\
\hline 9 & Baker [1] & Twitter \\
\hline 10 & $\begin{array}{l}\text { Francesco \& Jess } \\
\text { [4] }\end{array}$ & Viral videos \\
\hline 11 & Tyler [18] & Viral videos \\
\hline 12 & Burgess [2] & Viral videos \\
\hline 13 & Hilderbrand [7] & YouTube \\
\hline 14 & $\begin{array}{l}\text { Southgate, } \\
\text { Westoby and } \\
\text { Graham [13] }\end{array}$ & Viral videos \\
\hline 15 & $\begin{array}{l}\text { Sagan, Paul and } \\
\text { Tom [12] }\end{array}$ & Viral videos \\
\hline 16 & Wallsten [20] & $\begin{array}{l}\text { Viral videos, Blogosphere, } \\
\text { YouTube }\end{array}$ \\
\hline 17 & Jason [8] & $\begin{array}{l}\text { Facebook, Google+, LinkedIn, } \\
\text { Twitter, Instagram, Reddit }\end{array}$ \\
\hline 18 & Lupton [9] & $\begin{array}{l}\text { Twitter, LinkedIn, Facebook, } \\
\text { YouTube, Google+, Blogs, } \\
\text { Pinterest, SlideShare, Instagram, } \\
\text { Tumbler }\end{array}$ \\
\hline 19 & Heath [5] & Viral news \\
\hline 20 & $\begin{array}{l}\text { Nisbett and } \\
\text { Wilson [11] }\end{array}$ & Viral news \\
\hline
\end{tabular}

Table 2 presents the frequency of work done on a specific topic by the researchers. The word 'topic' has been used synonymously with the word 'platform' as well as the 'issues pertaining to social media' and 'the analysis' thereof. This has also been used for ordering the Table 2 by sorting it.

Further, in order to get a clearer picture of the research works done, the similar topics have been merged together. For instance, 'Blogosphere' and 'Blog' have been merged together into 'Blogs' in Table 2. Similarly, 'Buzz Marketing', 'WOM' and 'Viral Marketing' have been merged together in Table 2 into 'Buzz Marketing'.

Based on the analysis of Fig. 1, it has been found that maximum of the researchers has worked on Viral Video. This is followed by the second highest works by researchers on 'Facebook'. It is noteworthy to mention here that Facebook is a major player in the Social Media industry. It is also a key factor responsible for proliferation of social media, specifically the online social media on the internet and cyber world. This is further followed by 'LinkedIn' and 'Twitter' at third position. The fourth position is shared by 'Buzz Marketing', 'Google+' and 'YouTube'. Similarly, the minimum numbers of research works have been found on four topics with last position equally shared by 'Pinterest', 'Reddit', 'SlideShare' and 'Social Media'.

Table 2. Frequency Tabulation of Paper Highlights

\begin{tabular}{|c|c|c|}
\hline Sr. No. & Paper Highlight & Frequency \\
\hline 1 & Facebook & 5 \\
\hline 2 & LinkedIn & 4 \\
\hline 3 & Twitter & 4 \\
\hline 4 & Google+ & 3 \\
\hline 5 & Tumbler & 2 \\
\hline 6 & Social Media & 1 \\
\hline 7 & Buzz Marketing & 3 \\
\hline 8 & Viral Videos & 6 \\
\hline 9 & YouTube & 3 \\
\hline 10 & Blogs & 2 \\
\hline 11 & Instagram & 2 \\
\hline 12 & Reddit & 1 \\
\hline 13 & Pinterest & 1 \\
\hline 14 & SlideShare & 1 \\
\hline 15 & Viral news & 2 \\
\hline
\end{tabular}

The graphical representation of the data presented in Table 2 is depicted through Fig. 1.

On the sidelines of the review work, it is also found that there are some parameters that influence the use of social media. Some of them are age, gender, academic education, workplace, social influence, oddness, presentation, creativity, availability of sites, content freshness, and relevance. 


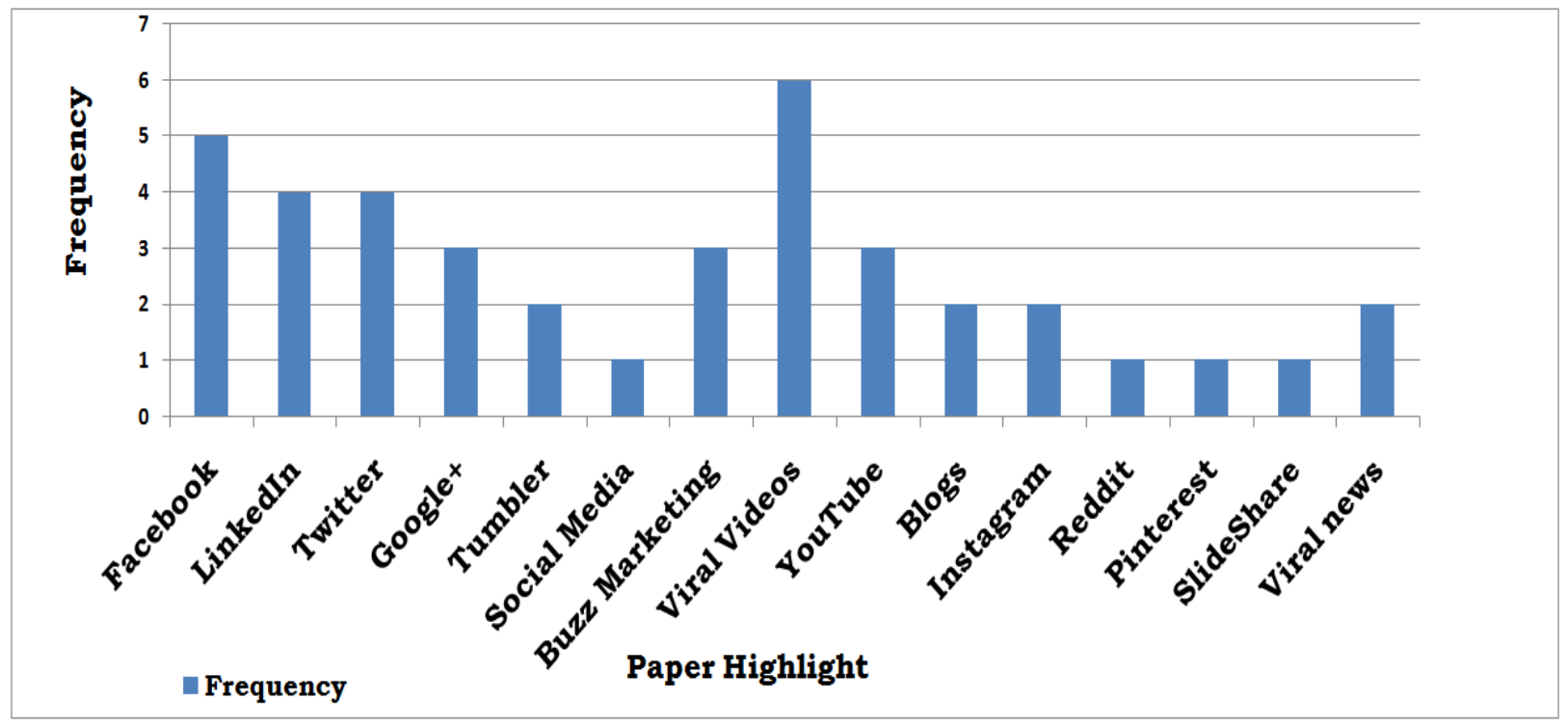

Fig 1: Graphical Depiction of Frequency of Paper Highlights

\section{CONCLUSION}

It is concluded that social networking sites like Facebook, LinkedIn, Twitter and YouTube are big hit because people are always interested to know about others life and affairs. Through social media emotions themselves might spread over networks to generate large scale attachment that gives rise to clusters of happy and unhappy individuals. There is always a risk of spreading of viral "negatively". It is easy to spread a video changing its meaning and showing it as bad viral. Thus a video getting viral is directly related to the way in which it influences various categories of users and interest of a user in a particular area.

Videos that can produce anger are more likely to spread. There is a deep connection between contents of the video and that video getting viral. It is further concluded that most of the researchers have worked on Viral Video, Facebook and LinkedIn and very less work has been done by the researchers on other social media like Pinterest, Reddit and SlideShare. This paper will further work in the direction of analysis of these areas which have not been touched by the researchers in the past.

The paper does not claim that this is exhaustive research neither promotes nor discourages any social media usage.

\section{REFERENCES}

[1] Baker B., "Your customer is talking - to everyone; Social media in the new channel for Customer connection," Information Management, New York, 2009, May 1, Vol. 19, Iss. 4; pp. 1-4

[2] Burgess J., "All Your Chocolate Rain Are Belong To Us?: Viral Video, YouTube and the Dynamics of Participatory Culture", Institute of Network Cultures, 2008. Available online: http://eprints.qut.edu. au/18431/1/18431.pdf; Last accessed: 15-Feb-2015

[3] Fisher T., "ROI in social media: A look at the arguments," Database Marketing \& Customer Strategy Management, 2009, vol. 16, 3, pp. 189-195.

[4] Francesco D. and Jess, "How Stuff Spreads: How Videos go Viral", Nov. 11, 2013, Available Online: http://www.facegroup.com/blog/how-videos-goviral.html; Last accessed: 15-Feb-2015
[5] Heath D., "Modest Interventions", Cyborgs and Citadels, Santa Fe: School of American Research, 1996, pp. 6782.

[6] Hempel J., "LinkedIn: How It's Changing Business". Fortune, 2013, pp. 69-74.

[7] Hilderbrand L., "YouTube: Where Cultural Memory and Copyright Converge", Film Quarterly, 61, pp. 48-58. Available

Online: http://caliber.ucpress.net/doi/abs/10.1525/fq.2007.61.1.4 8; Last accessed: 15-Feb-2015

[8] Jason M., "globalwebindex- GWI social summary 2014", Head of Trends, 2014

[9] Lupton D., "Feeling Better Connected': Academics", Use of Social Media, News \& Media Research Centre, University of Canberra, 10 June 2014.

[10] Marketing Land, Two years later, Google+ Hits 300 Million Active Monthly "In-Stream" Users, 540 Million Across Google, October 29, 2013.

[11] Nisbett R. E. and Wilson T. D., "Telling more than we can know: Verbal report on mental processes", Psychological Review, 1977, 84 (3), pp. 231-259.

[12] Sagan, Paul and Tom L., "The Internet and the Future of News", Daedalus, vol. 139, iss. 2, 2010. Available Online:

http://www.mitpressjournals.org/doi/pdf/10.1162/daed.2 010.139.2.119; Last accessed: 15-Feb-2015

[13] Southgate, Westoby and Graham P., "Creative determinants of viral video viewing", International Journal of Advertising", 2010, vol. 29, pp. 349-368. Available

Online: www.millwardbrown.com/.../Creative_Viral_PotentialIAJ_v29n4_2010.sflb.ashx; Last accessed: 15-Feb-2015

[14] Stelzner M., "Social Media Marketing Industry Report, 2013", Social Media Examiner, 2013.

[15] Subramani M. R. and Rajagopalan B., "Knowledgesharing and influence in online social networks via viral Marketing", Communications of the ACM, 2003, vol. 46, iss. 12 , pp. $300-307$. 
[16] Tumbler "About Us", Tumbler. Retrieved September 1, 2014.

[17] Twitter, "Twitter turns six". Twitter; March 21, 2012.

[18] Tyler W., "Broadcast Journalism and International Studies", Elon University.

[19] BBC News, University of California, Yale.

[20] Wallsten K., "Yes We Can: How Online Viewership, Blog Discussion and Mainstream Media Coverage Produced a Viral Video Phenomenon”, 2008, California State University, Long Beach, pp. 1- 177. Available Online: http://www.jitp.net/files/v007002/JITP72_YesWeCan.pdf; Last accessed: 15-Feb-2015

[21] Social media, Wikipedia, Available Online: http://en.wikipedia.org/wiki/Social media; Last accessed: 15-Feb-2015

[22] Facebook, Wikipedia, Available Online: http://en.wikipedia.org/wiki/Facebook; Last accessed: 15-Feb-2015

[23] LinkedIn, Wikipedia, Available Online: http://en.wikipedia.org/wiki/LinkedIn; Last accessed: 15Feb-2015

[24] Steven J., Social enterprise, ZDNet, Available Online: http://www.zdnet.com/article/facebook-remains-topsocial-network-google-youtube-battle-for-second; Last accessed: 15-Feb-2015

[25] Tumblr, Wikipedia, Available Online: http://en.wikipedia.org/wiki/Tumblr; Last accessed: 15Feb-2015

[26] Jess O., How Stuff Spreads: How Videos Go Viral, Part I, Available Online: http://www.facegroup.com/blog/author/jess; Last accessed: 15-Feb-2015
[27] Twitter, The Big Wiki, Available Online: http://www.thebigwiki.com/wiki/twitter; Last accessed: 15-Feb-2015

[28] YouTube, Wikipedia, Available Online: http://en.wikipedia.org/wiki/YouTube; Last accessed: 15-Feb-2015

[29] StumbleUpon, Wikipedia, Available Online: http://en.wikipedia.org/wiki/StumbleUpon; Last accessed: 15-Feb-2015

[30] Digg, Wikipedia, Available Online: http://en.wikipedia.org/wiki/Digg; Last accessed: 15Feb-2015

[31] Saini J.R., "Self Learning Taxonomical Classification System Using Vector Space Document Analysis Model for Web Text Mining in UBE", Ph.D. Thesis guided by Dr. A.A. Desai, accepted by Department of Computer Science, Veer Narmad South Gujarat University, Surat, Gujarat, India; 2009

[32] Saini J.R. and Desai A.A., "Structural Analysis of Username Segment in E-Mail Addresses of MCA Institutes of Gujarat State", published in The IUP Journal of Information Technology (ISSN: 0973-2896), vol. 6, issue 3, pp. 43-50; 2010

[33] Saini J.R., "Psychoanalysis of Online Behavior and Cyber Conduct of Chatters in Chat Rooms and Messenger Environments", published in the International Journal of Advanced Networking and Applications (ISSN: 0975-0290), vol. 6, issue 2, pp. 2214-2221; 2014

[34] Saini J.R. and Desai A.A., "A Textual Analysis of Digits Used for Designing Yahoo-group Identifiers", published in The IUP Journal of Information Technology (ISSN 0973-2896), vol. 6, issue 2, pp. 34-42; 2010 